\title{
Use of Nested and Real-Time PCR for the Detection of Ceratocystis fagacearum in the Sapwood of Diseased Oak Species in Minnesota
}

\author{
A. Yang, University of Minnesota, St. Paul 55108; and J. Juzwik, United States Department of Agriculture Forest Service, Northern Research \\ Station, St. Paul, MN 55108
}

\begin{abstract}
Oak wilt caused by Ceratocystis fagacearum is a significant disease of Quercus spp. in the eastern United States. Early and accurate detection of the pathogen is particularly important when disease control is planned. Nested and real-time polymerase chain reaction (PCR) methods utilizing fungal DNA extracted from sapwood drill shavings of red, bur, and white oak at different stages of disease development were compared with culture-based detection from sapwood. The pathogen was detected in all $(n=3)$ actively wilting branches of each of nine red oak trees using all three methods. The lowest detection rate (33\% of assayed branches;

6 of 8 trees) for actively wilting branches was found for white oak using isolation while nested PCR had a branch detection rate of $100 \%$ ( 8 of 8 trees) and real-time PCR of $87 \%$ ( 8 of 8 trees) for the same samples. For both bur and white oak, the pathogen was not detected by isolation in branches over 1 year after their death but was detected using both PCR methods. Only the PCR assays detected the fungus in sapwood samples underlying remnants of sporulation mats $(n=21 ; 90 \%$, nested and $62 \%$, real-time) on red oak. These PCR methods offer several significant improvements for laboratory-based detection methods of $C$. fagacearum.
\end{abstract}

Oak wilt, caused by the fungus Ceratocystis fagacearum (Bretz) J. Hunt, is an important disease of oak in the eastern United States and in Texas. Epidemics are currently ongoing in portions of the Great Lake States and Texas (Juzwik et al. 2011). If left unmanaged, oak wilt has the ability to dramatically alter both urban and natural ecosystems (Appel 1995). Oak (Quercus) species differ in their susceptibility to the disease. Members of the white oak group (section Quercus), such as Quercus macrocarpa and Q. alba, are moderate to low in susceptibility based on disease severity, with symptoms ranging from scattered branch dieback in the crown to death of a single limb or major stem fork (Juzwik et al. 2011). In contrast, members of the red oak species (section Lobatae) succumb within months to 1 year following infection by $C$. fagacearum. Although this variation in rate of disease progression exists, no Quercus sp. is immune to the disease.

In red oak species, the rapid development of leaf bronzing, first in the upper crown and then throughout the crown, is a classic visual symptom. However, this symptom may be confused with damage from bacterial leaf scorch (Xylella fastidiosa) and from rapid infestation by the two-lined chestnut borer (Agrilus bilineatus) (Gould and Lashomb 2007; Haack and Acciavatti 1992). The inconsistent nature of symptoms within species of the white oak group is even more problematic for making a diagnosis based on crown symptoms. Insect pests, abiotic factors, and other pathogens may cause similarlooking crown symptoms in white oak species (Juzwik et al. 2011). In scenarios where management is justified, an accurate and timely lab diagnosis is critical.

Guidelines for collecting appropriate branch and main-stem samples from suspect oak trees in the northern states have been published (Pokorny 1999). Currently, processing of samples in a diagnostic laboratory involves standard pathogen isolation methods (Pokorny 1999). An incubation period of 10 to 14 days is commonly needed before characteristic fungal colony morphology and microscopic features are evident. Although this method is successful in detecting C. fagacearum, it has significant limitations related to sample quality

Corresponding author: A. Yang; E-mail: yang1148@umn.edu

Accepted for publication 11 November 2016.

This article is in the public domain and not copyrightable. It may be freely reprinted with customary crediting of the source. The American Phytopathological Society, 2017. that may lead to a false-negative result. For example, desiccated branch samples and samples that have been overheated prior to laboratory submission result in poor-quality material from which the pathogen is unlikely to be isolated. Furthermore, C. fagacearum is a poor saprophyte, making it very difficult to culture from dead or moribund material that has been colonized by secondary microorganisms. Thus, there is a need for a rapid, practical assay that is not exclusively dependent on the ability to culture the fungus.

Molecular-based methods for pathogen detection have emerged as useful tools for plant disease diagnosis due to the advantage of speed and sensitivity (McCartney et al. 2003; Schena et al. 2004). Molecular assays such as nested and real-time polymerase chain reaction (PCR) are often less laborious than traditional detection methods and have the ability to provide faster and more sensitive results. The ribosomal DNA (rDNA) internal transcribed spacer (ITS) region is commonly used in primer development for detection of or distinguishing among similar fungal species using PCR (Schoch et al. 2012). Wu et al. (2011) reported a nested PCR assay for $C$. fagacearum using species-specific primers based on the rDNA ITS region. The developed primers allowed for successful amplification of C. fagacearum DNA that had been extracted from artificially inoculated, sterile wood strips ( 3 by 1 by $0.2 \mathrm{~cm}$ ).

Real-time PCR protocols utilizing the rDNA ITS region have been developed for the rapid detection and quantification of plant pathogens in soil and plant material (Kurdyla and Appel 2011; Samuelian et al. 2011; Sikdar et al. 2014; Wu et al. 2011). Specific primers and a fluorescent-labeled probe have been developed for use with real-time PCR for the detection of $C$. fagacearum in spore suspensions from a pure culture, purified target DNA, and wood shavings from mainstem samples of symptomatic live oak and Monterey oak trees in Texas (Kurdyla and Appel 2011). Other examples of fungal DNA extraction directly from xylem tissues of tree species in situ have been published (Guglielmo et al. 2007, 2010; Lindner et al. 2011). These methods eliminate the need to obtain a pure culture of a pathogen prior to DNA sequencing. The application of these techniques to detect $C$. fagacearum DNA in diseased northern oak species offers the potential to dramatically improve the speed and specificity of laboratory diagnosis.

The aim of this study was to evaluate a nested PCR and real-time PCR protocol for the detection of $C$. fagacearum in the sapwood of actively wilting oak trees as well as from tissues taken the year following branch or whole-tree death. If the methods proved accurate and reliable, guidelines for their use could be developed to complement the current diagnostic standards used by plant disease diagnostic 
laboratories. This report details results for the comparison of nested PCR, real-time PCR, and standard isolation methods for four oak species commonly affected by $C$. fagacearum in the Upper Midwest of the United States. A preliminary report on the nested PCR protocol has been published (Yang et al. 2014).

\section{Materials and Methods}

Sampling sites and protocols. In 2012, seven locations with actively wilting red (Quercus rubra or Q. ellopsoidalis), bur (Q. macrocarpa), or white oak ( $Q$. alba) trees were selected within the Minneapolis-St. Paul, MN metropolitan area. Sampling sites were located within the communities of Apple Valley, Arden Hills, Eagan, Minnetonka, North Branch, Oakdale, and St. Paul. Trees that had previously tested positive for oak wilt were located with the aid of city foresters and commercial arborists. Within each community, one to three sites were chosen for sampling. Three branches (5.0 to $7.6 \mathrm{~cm}$ in diameter) were collected from the crowns of nine red, eight bur, and eight white oak trees with actively wilting leaves, as described by Pokorny (1999), between mid-July and late August. Four subsections ( 20.3 to $30.5 \mathrm{~cm}$ long) were cut from each branch, sealed in plastic bags, and stored on ice for transport to the laboratory. At the laboratory, all samples were stored at $4{ }^{\circ} \mathrm{C}$ until they were further processed. In addition, three branches were collected from the crowns of two apparently healthy trees of each species to serve as controls. Control tree samples were handled in the same manner as those from symptomatic trees.

In 2013, multiple locations in the Minneapolis-St. Paul, MN metropolitan area were again selected for sampling. The locations included the communities of Apple Valley, North Branch, Forest Lake (Carlos Avery Wildlife Management Area), East Bethel (Cedar Creek Ecosystem Science Reserve), and St. Paul. Dead branches were sampled in July and August of 2013 from three bur and four white oak trees with crown dieback. The sampled branches were taken from the same wilting trees used in the previous year and were estimated to have died between mid-August and early September 2012. The branches were processed in the same manner as the branches sampled in 2012. Three dead branches were sampled from the crowns of two non-oak-wilt-affected bur and white oak trees for use as controls. Control trees were sampled from the communities of St. Paul (Battle Creek Regional Park) and Rogers (Crow-Hassen Park Reserve).

In lieu of branch samples, it is common practice for forest health professionals to take lower stem sapwood samples from red oak trees following wilt and whole-tree death. In August 2013, sapwood "windows" of approximately 20.3 by $17.8 \mathrm{~cm}$ were cut with a chainsaw from the exposed sapwood of four trees exhibiting vascular staining characteristic of $C$. fagacearum colonization. The same sampling method was used on two trees exhibiting chestnut-brown-colored cambium (which develops following vascular staining).

Three fresh oak wilt mats on each of seven red oak trees with crowns that had completely wilted the previous summer were marked in early June 2013. In late August 2013, following tree death, samples were taken from the sapwood underlying the sooty-mass remains of the oak wilt mats (mat scar) using the same process as for the discolored sapwood windows. Lower stem sapwood controls were obtained by removing three bark windows to expose cambium on the stems of two healthy red oak trees in Rogers, MN. All sapwood samples were sealed in a plastic bag, stored on ice, and transported to the laboratory. The samples were stored in the laboratory at $4^{\circ} \mathrm{C}$ until processed.

Processing using standard isolation protocols. All branch and stem samples were processed using published isolation protocols (Pokorny 1999). Samples were surface sterilized by spraying the sample with $95 \%$ ethanol and briefly flaming. The bark was removed with a sterile drawknife to reveal any outer sapwood discoloration. Four small $\left(0.4 \mathrm{~cm}^{2}\right)$ pieces of stained sapwood were removed with a flame-sterilized wood gouge and forceps. The pieces were placed on acidified ( $20 \%$ lactic acid at $5 \mathrm{ml} / \mathrm{liter})$ potato dextrose agar in 100 -mm-deep petri plates. The plates were incubated at room temperature (approximately $24^{\circ} \mathrm{C}$ ) under ambient lighting and checked regularly for the presence of the fungus. Plates were held for a maximum of 14 days. Plated wood chips that yielded mixed fungal species were subcultured until pure cultures were obtained. Pure cultures of $C$. fagacearum were identified by the presence of gray to olive-green colonies, characteristic fruity odor, and presence of endoconidia.

DNA extraction. Drill shavings were obtained from each branch and stem sample with the following modifications of Guglielmo et al. (2010). Previously exposed but undisturbed portions of branch and stem segments from which wood pieces had been obtained from the isolation protocol were sampled for the molecular assay. Shavings were created by drilling in and out of the sapwood several times using a bleach-sterilized (10\% commercial bleach solution), 9.5-mmdiameter drill bit. The conical end of a $1.5-\mathrm{ml}$ microcentrifuge tube was removed to create a sterile "microfunnel." The shavings adhering to the drill bit were dislodged in the microfunnel. When the microfunnel was full, shavings were pushed through the funnel into a sterile 2-ml microcentrifuge tube. The procedure was repeated at three to five locations on the sample until approximately $1 \mathrm{ml}$ of shavings was obtained. The resulting drill shavings were stored at $-20^{\circ} \mathrm{C}$ until DNA was extracted.

Drill shavings in each tube were mixed using a sterile metal spatula and 0.18 to $2.0 \mathrm{~g}$ of drill shavings was transferred to a new, sterile 2 - $\mathrm{ml}$ microcentrifuge tube containing two metal beads $(4.5 \mathrm{~mm}$ in diameter). The metal beads had been sterilized in a $10 \%$ commercial bleach solution for $5 \mathrm{~min}$ followed by a rinse with molecular-grade water. Lysis buffer (1.4 ml; QIAmp DNA Stool Kit; Qiagen, Venlo, The Netherlands) was added to each tube. Each sample was homogenized by vortexing for $60 \mathrm{~s}$. DNA was then extracted from samples using a QIAmp DNA Stool Kit (Qiagen) according to the manufacturer's instructions.

Nested PCR. Amplification of fungal DNA was accomplished using a nested PCR protocol. The first round of PCR was completed with the general fungal primer pair ITS1-F (5'-TCCGTAGGTGA ACCTGCGG-3') and ITS4 (5'-TCCTCCGCTTATTGATATGC-3'). Each 25- $\mu$ l reaction contained $12.5 \mu \mathrm{l}$ of GoTaq Green (Promega Corp., Madison, WI), $0.5 \mu \mathrm{l}$ of primer ITS1F $(10 \mu \mathrm{M}), 0.5 \mu \mathrm{l}$ of primer ITS4 $(10 \mu \mathrm{M}), 2.0 \mu \mathrm{l}$ of genomic DNA, and $9.5 \mu \mathrm{l}$ of molecular-grade water. The second round of PCR was completed with C. fagacearum-specific primers CF01 (5'-GGCGACTTCTTTCTT-3') and CF02 (5'-AAGGCTTGAGTGGTGAAA-3'), developed by Wu et al. (2011). Each $25-\mu 1$ reaction contained $12.5 \mu l$ of GoTaq Green, $0.5 \mu \mathrm{l}$ of primer CF01 $(10 \mu \mathrm{M}), 0.5 \mu$ l of primer CF02 $(10 \mu \mathrm{M}), 1.0 \mu \mathrm{l}$ of product from the first round of PCR, and $10.5 \mu 1$ of molecular-grade water. DNA amplification was conducted on a Mastercycler (Eppendorf AG, Hamburg, Germany) as follows: $94^{\circ} \mathrm{C}$ for $2 \mathrm{~min} ; 35$ cycles of $94^{\circ} \mathrm{C}$ for $30 \mathrm{~s}, 52^{\circ} \mathrm{C}$ for $30 \mathrm{~s}$, and $72^{\circ} \mathrm{C}$ for $2 \mathrm{~min}$; and a final extension of $72^{\circ} \mathrm{C}$ for $7 \mathrm{~min}$. PCR products were held at $18^{\circ} \mathrm{C}$ until visualized on a $2 \%$ agarose gel. Negative controls lacking template DNA were used in each experiment to test for contamination. Products from the second round of PCR were visualized on a $2 \%$ agarose gel with an expected amplicon size of $280 \mathrm{bp}$.

DNA sequencing. Sequencing reactions of second-round PCR products were performed following the BigDye terminator protocol (Applied Biosystems, Life Technologies, Waltham, MA) with primer CF02. Second-round PCR products were cleaned with CleanSeq (Agencourt, Brea, CA) magnetic beads following the manufacturer's protocol and sequenced using an ABI 3730xl DNA Sequencer (Applied Biosystems, Life Technologies) at Functional Biosciences (Madison, WI).

Sequences were examined using Sequencher (version 5.2 sequence analysis software, Gene Codes Corporation, Ann Arbor, MI) and Four Peaks (version 1.7.1; Nucleobytes B.V., Aalsmeer, The Netherlands). Sequence quality was evaluated and appropriate trimming was performed. $C$. fagacearum DNA sequences were identified using BLASTn $(98 \%$ identity for sequences, $>200 \mathrm{bp})$ to closely matching fungal accessions in the GenBank nucleotide sequence database.

Real-time PCR. Real-time PCR was performed using a Smartcyler (Cepheid, Sunnyvale, CA). Reactions were completed with the forward primer CfP2-01 (5'-TGGCAGGGACTTCTTTCTTCA-3'), 
reverse primer CfP2-02 (5'-TGGTTAAATGCAACTCAGCAAT GA-3'), and probe CfP2 (5'-156-FAM/ATGTTTCTGCCAGTA GTATT/3BHQ_1/-3') developed by Kurdyla and Appel (2011). Each $25-\mu$ l reaction contained $10 \mu$ l of 5 Prime Real Mastermix (5 Prime, Gaithersburg, MD), $0.5 \mu \mathrm{l}$ of each primer $(200 \mathrm{nM})$ and probe $(200 \mathrm{nM}), 1 \mu \mathrm{l}$ of extracted genomic DNA, and $12.5 \mu \mathrm{l}$ of molecular-grade water. Reactions were performed under the following conditions: $94^{\circ} \mathrm{C}$ for $2 \mathrm{~min}, 40$ cycles of $95^{\circ} \mathrm{C}$ for $15 \mathrm{~s}$, and $60^{\circ} \mathrm{C}$ for $1 \mathrm{~min}$ to calculate the cycle threshold $(\mathrm{Ct})$ values for each sample. All reactions were performed in duplicate and included parallel reactions of three separate dilution series of pure standard DNA and a control free of any template DNA.

A standard curve was constructed by using 10 serial dilutions of gel-purified C. fagacearum PCR product $(26.5 \mathrm{ng} / \mu \mathrm{l})$ generated from the nested PCR protocol nested PCR. Each sample was amplified in triplicate. To obtain the slope of the real-time PCR standard curve, the log transformation of the DNA concentration (x-axis) was plotted against the average $\mathrm{Ct}$ value (y-axis) for each sample. Efficiency of the assay was calculated by using the formula $E=$ $10^{\text {(1/-slope) }}-1 \times 100$ (Ginzinger 2002).

Statistical analyses. A logistic-normal mixed model analysis (Agresti 2002) was used to identify differences in detection between nested PCR, real-time PCR, and traditional isolation methods. The same model was also used to obtain predicted probabilities of detecting the fungus from actively wilting branch segments. The logisticnormal mixed model has the form:

$$
\begin{gathered}
\text { L1: } Y_{i j k l} \sim \text { Bernoulli }\left(P_{i j k l}\right) \\
\operatorname{Logit}\left[P\left(Y_{i j k l}=1\right)\right]=\mu+S_{i}+D_{j}+S x D_{i j}+\alpha_{k}+\beta_{l(k)} \\
\text { L2: } \alpha_{k} \sim N\left(0, \sigma_{\text {Tree }}^{2}\right), \beta_{l(k)} \sim N\left(0, \sigma_{\text {Branch }}^{2}\right),
\end{gathered}
$$

where $P$ is the probability of detecting the fungus, $\mu$ is the overall mean, $S$ is the oak species variable, $D$ is the diagnostic method variable, $\alpha$ is the error associated with tree, and $\beta$ is the error associated with branch. The model was run as a hierarchical generalized linear mixed model with PROC GLIMMIX of SAS (version 9.3 of the SAS system for Windows platform; SAS/STAT Institute, Cary, NC). Numerator and denominator degrees of freedom were calculated by the Kenward-Roger's approximation within PROC GLIMMIX of SAS. The probability of detecting the fungus from each species using each of the three methods was calculated using a logit transformation.

An exact Wilcoxon rank sum test was used to test for differences in pathogen detection between dead bur and white oak branches for all three detection methods. A Wilcoxon ranked sign test was then used to test for differences in the proportion of positive branches between methods within dead branches of the bur and white oak trees.

McNemar's test (Agresti 2002) was used to determine whether or not the marginal probabilities of pathogen detection in red oak mat scars and windows were the same between the three detection methods used. All calculations with McNemar's test were performed using R (version 3.0.2) (R Core Team 2013). Multiple $P$ value corrections were performed using the Bonferroni-Holm adjustment

Table 1. Detection of Ceratocystis fagacearum in branch subsamples from actively wilting crowns of Quercus rubra and $Q$. ellipsoidalis (red oak), Q. macrocarpa (bur oak), and Q. alba (white oak) study trees using traditional isolation techniques ${ }^{\mathrm{a}}$

\begin{tabular}{lcccccccc}
\hline & \multicolumn{2}{c}{ Branch segments } & & \multicolumn{2}{c}{ Branch basis $^{\mathbf{b}}$} & & \multicolumn{2}{c}{ Tree basis $^{\mathbf{b}}$} \\
\cline { 2 - 3 } Oak species & Assayed & Positive & & Assayed & Positive & & Assayed & Positive \\
\hline Red & 108 & 105 & & 27 & 27 & & 9 & 9 \\
Bur & 96 & 59 & & 24 & 17 & & 8 & 7 \\
White & 96 & 22 & & 24 & 8 & & 8 & 6 \\
\hline
\end{tabular}

${ }^{a}$ Data shown are total number assayed and number positive.

${ }^{\mathrm{b}}$ Results of branch segment assays were composited by branch and by tree, with three branches per tree and four segments from each branch. for the 1-year-dead bur and white oak samples and also for the red oak main-stem samples.

\section{Results}

C. fagacearum detection by standard isolation. For current-year wilting red oak trees, $97 \%$ of the branch segments were positive using standard isolation techniques (Table 1). For bur oak, $64 \%$ of the branch segments were positive for the fungus using standard isolation. The fungus was only detected in $23 \%$ of the wilting white oak branch segments using standard isolation techniques. When summarized at the branch level, all wilting branches from red oak trees were positive for the fungus using isolation techniques. For bur oak, $71 \%$ of the branches were positive. In white oak trees, only $33 \%$ of the branches were positive for the fungus. When isolation results were compiled at the tree level, the pathogen was detected in all red oak trees, seven of eight bur oak trees, and six of nine white oak trees. The fungus was not detected in any of the control trees.

C. fagacearum was not isolated from dead bur and white oak branches that had completely wilted the previous year. In addition, the fungus was not cultured from any of the 1-year-old dead branches of control trees.

In red oak stems that were sampled approximately 1 year after wilting of the entire tree, the fungus was isolated from 11 of the 18 main-stem window subsamples from the trees with either a streaked cambium or uniform brown-colored cambium. The fungus was not isolated from any subsamples of the sapwood underlying the remnants of deteriorated sporulation mats on six trees. Finally, the fungus was not isolated from any of the control trees.

C. fagacearum detection by nested PCR. In actively wilting red oak trees, $94 \%$ of the subsamples from nine trees were positive for C. fagacearum using the nested PCR protocol (Table 2). In bur oak, the fungus was detected in $92 \%$ of the subsamples. In actively wilting white oak trees, $93 \%$ of subsamples were positive for the fungus using the nested PCR protocol. When the data were compiled on a branch basis, all of the branches sampled from red, bur, and white oak trees were positive for the fungus. In each of the species, at least one segment from each branch sampled was positive. Finally, when the data were compiled on a tree basis, each actively wilting tree assayed was determined to be positive for $C$. fagacearum.

In the 1-year-dead bur oak branches, the fungus was detected in $55 \%$ of branch segments $(n=36)$ whereas, in dead white oak branches, it was detected in $86 \%$ of branch segments $(n=48)$. In both species, at least one segment from each branch sampled was positive for the fungus.

In main-stem samples of red oak taken approximately 10 months after the crowns had completely wilted, nested PCR detected the pathogen in all windows removed from trees with either uniform brown-colored cambium or a streaked cambium. Nested PCR detected the fungus in $90 \%$ of the subsamples of the sapwood underlying the remnants of sporulation mats on seven trees (Table 3).

Real-time PCR standard curve generation. The detection limit for $C$. fagacearum in the real-time PCR assays was $0.3 \mathrm{fg}$, with the lowest DNA concentration having a Ct value of 31.7 (Fig. 1). A linear relationship was established between the log DNA concentration of detected C. fagacearum DNA and the Ct value of the PCR assay

Table 2. Detection of Ceratocystis fagacearum in branch subsamples from actively wilting crowns of Quercus rubra and $Q$. ellipsoidalis (red oak), $Q$. macrocarpa (bur oak), and $Q$. alba (white oak) study trees using nested polymerase chain reaction ${ }^{\mathrm{a}}$

\begin{tabular}{lcccccccc}
\hline & \multicolumn{2}{c}{ Branch segment } & & \multicolumn{2}{c}{ Branch basis $^{\mathbf{b}}$} & & \multicolumn{2}{c}{ Tree basis $^{\mathbf{b}}$} \\
\cline { 2 - 3 } Oak species & Assayed & Positive & & Assayed & Positive & & Assayed & Positive \\
\hline Red & 108 & 102 & & 27 & 27 & & 9 & 9 \\
Bur & 96 & 88 & & 24 & 24 & & 8 & 8 \\
White & 96 & 89 & & 24 & 24 & & 8 & 8 \\
\hline
\end{tabular}

${ }^{a}$ Data shown are total number assayed and number positive.

${ }^{\mathrm{b}}$ Results of branch segment assays were composited by branch and by tree, with three branches per tree and four segments from each branch. 
$\left(R^{2}=0.95985\right)$. Based on the slope of the standard curve, the amplification efficiency of the real-time PCR reactions was calculated to be $96.72 \%$.

C. fagacearum detection by real-time PCR. In actively wilting red oak trees, $75 \%$ of the branch segments from nine trees were positive for C. fagacearum using the real-time PCR protocol (Table 4). In wilting bur oak and white oak, the fungus was detected in at least $41 \%$ of the branch segments. For red oak trees, all of the branches sampled were positive whereas, in bur and white oak, $88 \%$ of the branches were positive for $C$. fagacearum. When we collapsed the data to the tree level, we found that all actively wilting trees assayed were positive for $C$. fagacearum using the real-time PCR protocol.

In 1-year-dead white oak branches, C. fagacearum was detected in 9 of the 48 subsamples using real-time PCR. The fungus was not detected in any of the 1-year-dead branches of bur oak trees using this method. In main-stem samples of red oak taken approximately 10 months after full wilt, real-time PCR detected the pathogen in 12 of 18 samples from trees with uniform brown-colored or vascular streaking in the cambium. The fungus was detected in two or more subsamples from five of the seven subsamples of sapwood underlying deteriorated sporulation mats (i.e., mat scars) (Table 5).

Comparison of detection methods. Overall, C. fagacearum was detected most frequently in actively wilting branch segments using the nested PCR protocol (Fig. 2). Differences $(P \leq 0.005)$ were found for species, diagnostic method, and species-diagnostic method for the data contained within actively wilting red, bur, and white oak trees based on logistic-normal mixed-model analysis of branch segment data (Table 6). When comparing the estimated and actual probabilities of detecting the fungus among the three detection methods, the nested PCR protocol had a higher probability of detecting the pathogen in actively wilting trees of the three oak species assayed (Table 7).

For the $\geq 1$-year-old dead bur and white oak branches, the proportion of segments in which the pathogen was detected was similar for both species using the traditional isolation method ( $\mathrm{W}=54$, adjusted

Table 3. Detection of Ceratocystis fagacearum from main-stem samples on Quercus rubra and Q. ellipsoidalis (red oak) trees 1 year after complete crown wilt using nested polymerase chain reaction ${ }^{\mathrm{a}}$

\begin{tabular}{|c|c|c|c|c|}
\hline \multirow[b]{2}{*}{ Sapwood sample typec } & \multicolumn{2}{|c|}{ Stem subsample } & \multicolumn{2}{|c|}{ Tree basis $^{\mathbf{b}}$} \\
\hline & Assayed & Positive & Assayed & Positive \\
\hline Window & 18 & 18 & 6 & 6 \\
\hline Mat scar & 21 & 19 & 7 & 7 \\
\hline
\end{tabular}

${ }^{a}$ Data shown are total number assayed and number positive.

${ }^{b}$ Results for three stem subsamples from each tree were composited on a whole-tree basis.

${ }^{c}$ Window $=$ sapwood sample removed from below cambium exhibiting vascular streaking or uniform brown in color and Mat scar = sapwood underlying remnant of fungus sporulation mat.

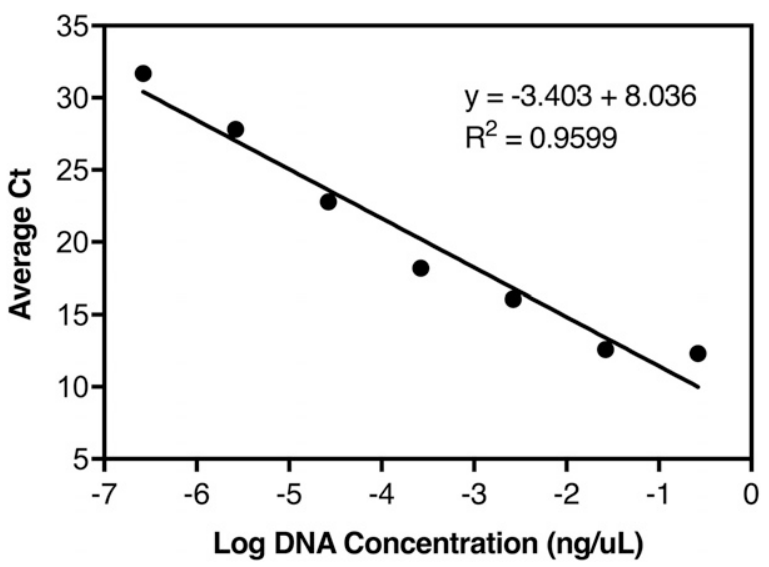

Fig. 1. Standard curve generated using genomic DNA from pure cultures of Ceratocystis fagacearum. A 10 -fold serial dilution of DNA concentrations from $0.265 \mathrm{ng} / \mu \mathrm{l}$ to $0.265 \mathrm{fg} / \mu \mathrm{l}$ was used in generating the standard curve.
$P=1.0)$ and real-time PCR $(\mathrm{W}=76.5$, adjusted $P=0.067)$ but differed with nested PCR (W $=96$, adjusted $P=0.0003$ ) (Fig. 3). Within each species, the Wilcoxon rank-sign test found differences in the proportion of branches in which the pathogen was detected in all of the method comparisons (adjusted $P>0.005$, Exact Wilcoxon rank sign test), with the exception of the isolation and real-time PCR comparison.

Similar probabilities of pathogen detection were found from sapwood windows of $\geq 10$-months-dead red oak and from sapwood sampled beneath mat scars using both molecular protocols (McNemar's $\chi^{2}=$ 4.1667, adjusted $P=0.0824$ for sapwood windows and McNemar's $\chi^{2}=2.5$, adjusted $P=0.1138$ for mat scars) (Fig. 4).

\section{Discussion}

Nested PCR and real-time PCR methods for the detection of C. fagacearum from currently wilting $Q$. rubra, $Q$. macrocarpa, and $Q$. alba branches were tested and compared with traditional isolation detection methods. The same methods were also tested on branches from $Q$. macrocarpa and $Q$. alba and main-stem samples from $Q$. rubra trees that had wilted the previous year. Overall, the nested PCR protocol proved to be the most accurate diagnostic method for detecting $C$. fagacearum from currently wilting oak trees and from 1-year-dead branches of Q. macrocarpa and Q. alba trees. When the real-time PCR protocol was compared with traditional isolation methods, there was no improvement in detection of the fungus in actively wilting red and bur oak branch samples; however, the realtime PCR protocol did yield a higher predicted probability of detection in white oak branch samples.

Similar results were obtained from stained sapwood from the lower main stem of wilted red oak ( 10 months, $>95 \%$ wilt $)$ with all three detection methods; however, the molecular protocols offer the potential to verify pathogen presence in older infected red oak by sampling dark-stained sapwood areas underlying highly deteriorated mats (mat scars). Until now, it has been widely accepted that the detection of $C$. fagacearum in dead or moribund trees via isolation was not possible because the fungus is no longer viable. This is the first report of detection of $C$. fagacearum in dead sapwood tissues of infected trees.

There are numerous advantages associated with the use of these new diagnostic protocols. A high priority was placed on the

Table 4. Detection of Ceratocystis fagacearum in branch subsamples from actively wilting crowns of Quercus rubra and Q. ellipsoidalis (red oak), Q. macrocarpa (bur oak), and $Q$. alba (white oak) study trees using real-time polymerase chain reaction ${ }^{\mathrm{a}}$

\begin{tabular}{lcccccccc}
\hline & \multicolumn{2}{c}{ Branch segment } & & \multicolumn{2}{c}{ Branch basis $^{\mathbf{b}}$} & & \multicolumn{2}{c}{ Tree basis $^{\mathbf{b}}$} \\
\cline { 2 - 3 } Oak species & Assayed & Positive & & Assayed & Positive & & Assayed & Positive \\
\hline Red & 108 & 81 & & 27 & 27 & & 9 & 9 \\
Bur & 96 & 39 & & 24 & 21 & & 8 & 8 \\
White & 96 & 43 & & 24 & 21 & & 8 & 8 \\
\hline
\end{tabular}

a Data shown are total number assayed and number positive.

${ }^{\mathrm{b}}$ Results of branch segment assays were composited by branch and by tree, with three branches per tree and four segments from each branch.

Table 5. Detection of Ceratocystis fagacearum from main-stem samples on Quercus rubra and Q. ellipsoidalis (red oak) trees 1 year after complete crown wilt using real-time polymerase chain reaction ${ }^{\mathrm{a}}$

\begin{tabular}{|c|c|c|c|c|}
\hline \multirow[b]{2}{*}{ Sapwood sample type } & \multicolumn{2}{|c|}{ Stem subsample } & \multicolumn{2}{|c|}{ Tree basis ${ }^{\mathbf{b}}$} \\
\hline & Assayed & Positive & Assayed & Positiv \\
\hline Window & 18 & 12 & 6 & 6 \\
\hline Mat scar & 21 & 13 & 7 & 5 \\
\hline
\end{tabular}

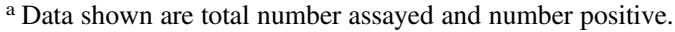

${ }^{b}$ Results for three stem subsamples from each tree were composited on a whole-tree basis.

${ }^{c}$ Window $=$ sapwood sample removed from below cambium exhibiting vascular streaking or uniform brown in color and Mat scar = sapwood underlying remnant of fungus sporulation mat. 
development of a diagnostic tool that could be easily adapted by plant disease diagnostic clinics that routinely process suspect oak wilt samples. The process of obtaining sapwood drill shavings may be easily adapted into the current oak wilt laboratory processing guidelines. The nested PCR protocol also has the benefit of taking only 2 to 3 days to obtain results, which is a significant improvement on the current 10- to 14-day incubation period for pathogen isolation.

The DNA extraction method used in this study employs a commercially available kit (QIAamp) that has previously been used to successfully detect fungi directly from wood (Guglielmo et al. 2007, 2010). Diagnosticians are often familiar with the use of Qiagen and other DNA extraction kits, which tend to minimize the handling of hazardous chemicals and are subjected to rigorous quality control.

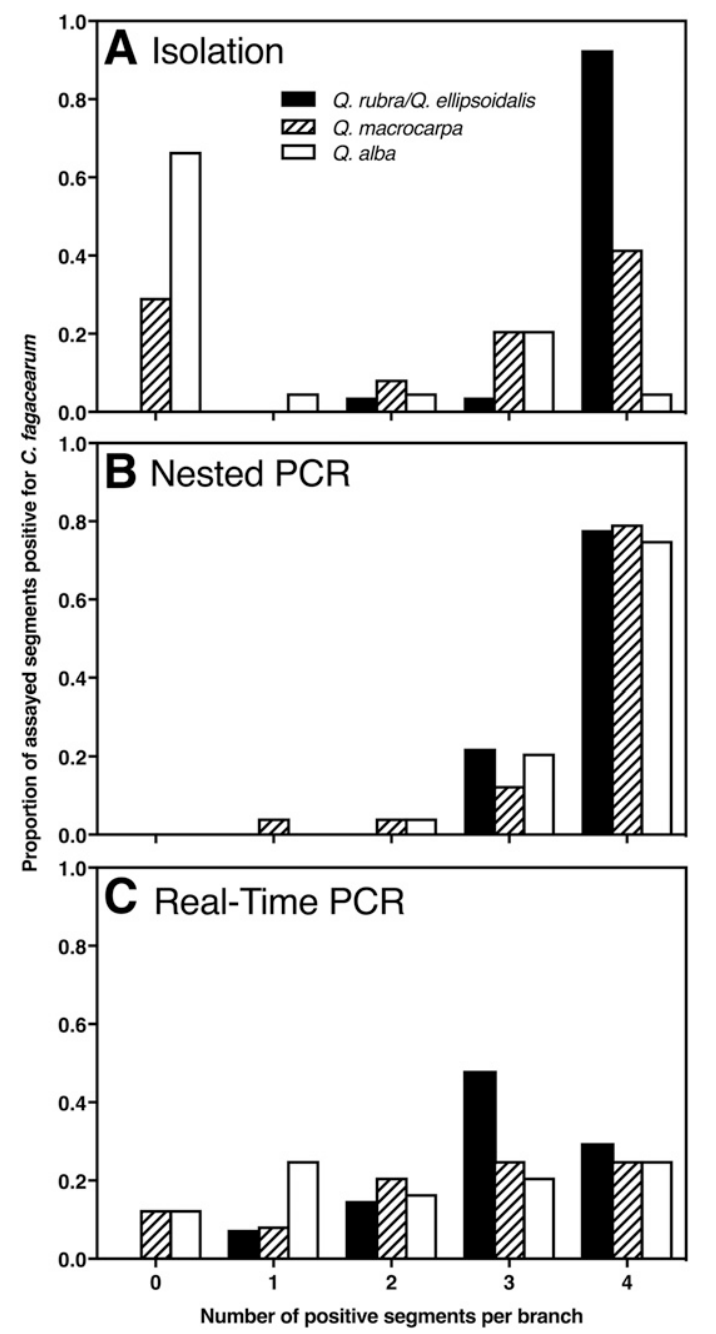

Fig. 2. Proportion of Ceratocystis fagacearum-positive branch segments based on total number of segments assayed from actively wilting Quercus rubra and Q. ellipsoidalis (red oak), Q. macrocarpa (bur oak), and Q. alba (white oak) trees using three laboratory detection protocols (A, isolation; $\mathbf{B}$, nested PCR; $\mathbf{C}$, real-time PCR).

Table 6. Model resulting from logistic-normal mixed-model analysis of variables that affect the likelihood of detecting Ceratocystis fagacearum in sapwood of actively wilting branches Quercus rubra and Q. ellipsoidalis (red oak), Q. macrocarpa (bur oak), and $Q$. alba (white oak) trees (type II tests of fixed effects)

\begin{tabular}{lccr}
\hline Effect & Numerator df $^{\mathbf{a}}$ & Denominator df $^{\mathbf{a}}$ & $\boldsymbol{P}$ value \\
\hline Oak species & 2 & 27.5 & 0.0016 \\
$\begin{array}{l}\text { Diagnostic method } \\
\begin{array}{l}\text { Species } \times \text { diagnostic } \\
\text { method }\end{array}\end{array}$ & 2 & 891.0 & $<0.0001$ \\
\hline
\end{tabular}

\footnotetext{
${ }^{\mathrm{a}}$ Degrees of freedom.
}

The use of molecular techniques for the rapid detection of plant pathogens has gained attention and molecular assays have been developed for different types of plant material and pathosystems (Sikdar et al. 2014). Similar assays utilizing primers based on the

Table 7. Models resulting from fixed-effect logistic-normal regression of the interactions of actively wilting branches of Quercus rubra and Q. ellipsoidalis (red oak), Q. macrocarpa (bur oak), and Q. alba (white oak) trees and diagnostic method used for detection of Ceratocystis fagacearum

\begin{tabular}{|c|c|c|c|c|c|}
\hline \multirow[b]{2}{*}{ Oak, method ${ }^{a}$} & \multirow[b]{2}{*}{ Estimate } & \multirow[b]{2}{*}{$\mathbf{S E}^{\mathbf{b}}$} & \multirow[b]{2}{*}{$P$ value } & \multicolumn{2}{|c|}{ Probability } \\
\hline & & & & Estimated $^{\mathrm{c}}$ & Actual $^{d}$ \\
\hline \multicolumn{6}{|l|}{ Red } \\
\hline Isolation & 4.1157 & 0.7729 & $<0.0001$ & 0.98 & 0.97 \\
\hline Nested PCR & 2.9659 & 0.5130 & $<0.0001$ & 0.95 & 0.94 \\
\hline Real-time PCR & 1.0170 & 0.3586 & 0.0079 & 0.73 & 0.75 \\
\hline \multicolumn{6}{|l|}{ Bur } \\
\hline Isolation & 0.5714 & 0.3774 & 0.1404 & 0.64 & 0.62 \\
\hline Nested PCR & 2.7396 & 0.4917 & $<0.0001$ & 0.94 & 0.92 \\
\hline Real-time PCR & 0.3133 & 0.3745 & 0.4096 & 0.58 & 0.41 \\
\hline \multicolumn{6}{|l|}{ White } \\
\hline Isolation & -1.3855 & 0.3972 & 0.0013 & 0.20 & 0.23 \\
\hline Nested PCR & 2.8187 & 0.5079 & $<0.0001$ & 0.94 & 0.93 \\
\hline Real-time PCR & 0.2485 & 0.3707 & 0.5081 & 0.56 & 0.45 \\
\hline
\end{tabular}

${ }^{a}$ Oak species and diagnostic method; $\mathrm{PCR}=$ polymerase chain reaction.

${ }^{\mathrm{b}}$ Standard error of the mean.

${ }^{\mathrm{c}}$ Estimated probability based on logit transformation from model estimates.

d Actual probability based on calculated proportions from samples used in this study.

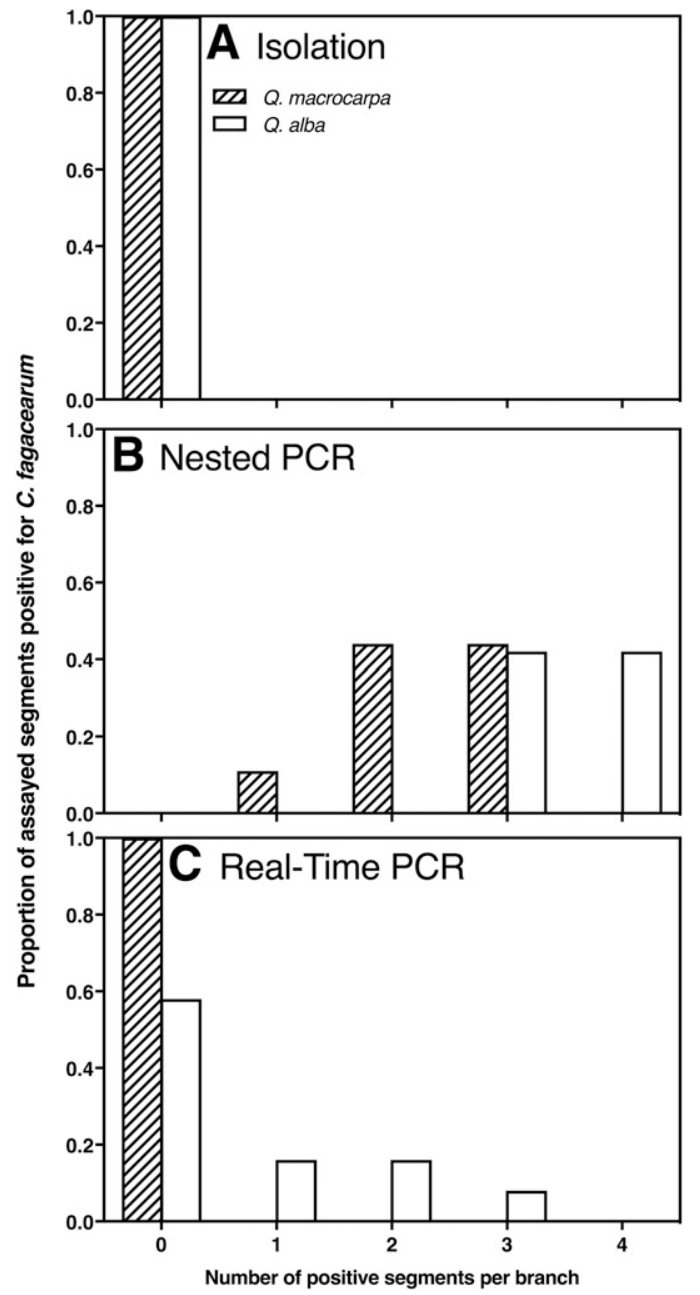

Fig. 3. Proportion of Ceratocystis fagacearum-positive branch segments based on total number of segments assayed from 1-year-dead branches of Quercus macrocarpa (bur oak) and Q. alba (white oak) trees using three laboratory detection protocols (A, isolation; B, nested PCR; C, real-time PCR). 
ITS region have successfully been developed for the detection of fungi directly from woody material for diseases such as laurel wilt (Raffaelea lauricola) and Verticillium wilt (Verticillium dahliae) on smoke tree (Cotinus coggygria) (Jeyaprakash et al. 2014; Wang et al. 2013). The drilling method used in this study was adapted from the Banik et al. (2013) sapwood sample collection kit developed to detect fungi in declining red pine. Similar to the material presented here, the assay for $R$. lauricola also utilized a commercially available DNA extraction kit. The value of these studies lies within their potential for simple routine use to detect pathogens and diagnose tree diseases.

DNA-based detection methods can lengthen the time frame in which successful oak wilt laboratory diagnosis may occur by allowing for detection from samples that have been degraded, exposed to high heat, or stored improperly prior to disease clinic submission. Bretz and Morrison (1953) found that $C$. fagacearum is no longer viable in small-diameter branches $(\leq 1.9 \mathrm{~cm})$ stored at $20^{\circ} \mathrm{C}$ for 6 days or more. Branch samples stored at $35^{\circ} \mathrm{C}$ had no viable fungus remaining after 3 days. It was also noted that, as the time interval between sample collection and isolation increased, the development of secondary organisms from the wood chips also increased. Thus, the detection of $C$. fagacearum can be very limited by environmental and sample storage conditions. With molecular methods, the detection of $C$. fagacearum DNA would not be limited by the poor survival of the fungus or the presence of contaminating microorganisms. Currently, successful fungal isolation from woodchips is restricted to time periods of foliar symptom development.

The detection of $C$. fagacearum in dead branch samples and red oak lower main stems creates new possibilities for management of

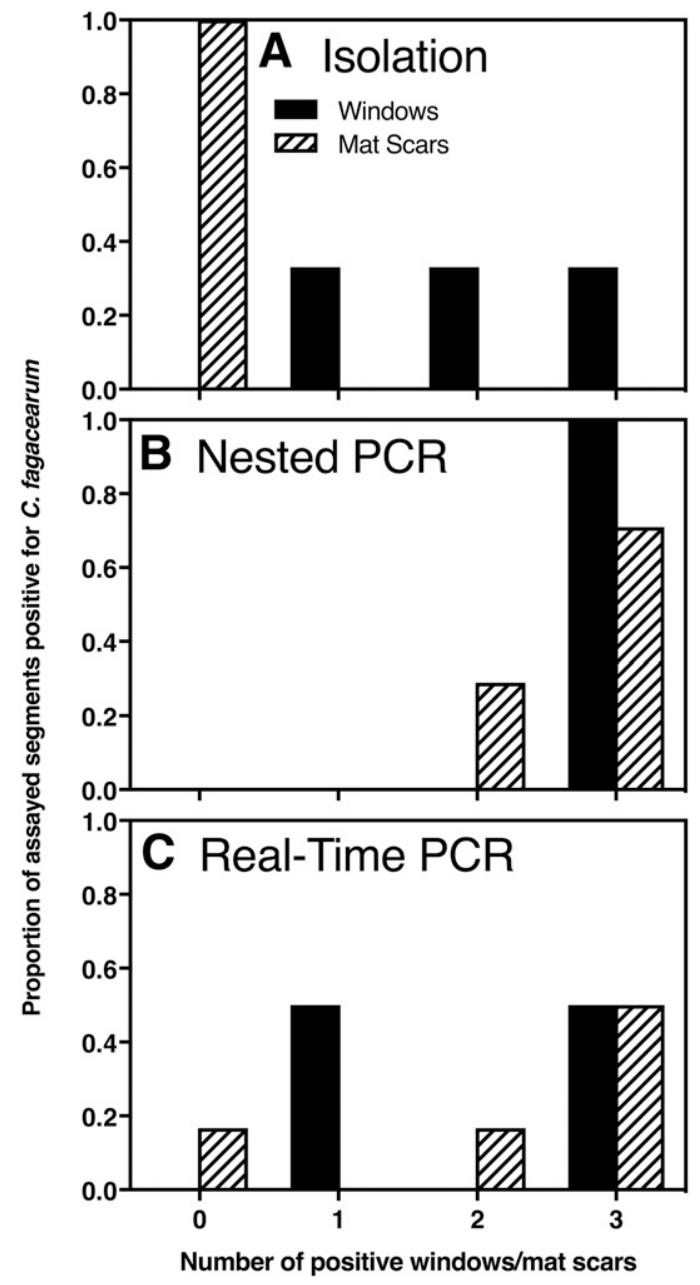

Fig. 4. Proportion of sapwood windows from 1-year-dead Quercus alba and Q. ellipsoidalis (red oak) trees that were positive for Ceratocystis fagacearum based on the total number of windows assayed from each tree using three laboratory detection protocols (A, isolation; $\mathbf{B}$, nested PCR; $\mathbf{C}$, real-time PCR). oak wilt in many scenarios. Detection of its presence is significant, even in situations where only the DNA from nonviable fungus material is available. Regardless of whether or not the fungus is viable, C. fagacearum remains a virulent pathogen in northern oak species and its detection would justify consideration of available and timely control actions. The scattered nature of oak wilt symptomatic branches in bur and white oak trees can limit the amount of material available for accurate pathogen testing using isolation methods. Branches that die as a result of the disease commonly exhibit black to brown discoloration in the outer sapwood. With the nested PCR method tested in this study, dead white and bur oak branches ( $\leq 1$ year dead) exhibiting sapwood discoloration caused by an oak wilt infection can be successfully used to detect $C$. fagacearum. The ability to detect the fungus from this type of material allows for detection and treatment, if justified, of high-value trees.

In red oak species, both of the molecular protocols evaluated in this study could provide the opportunity for a postmortem diagnosis of the disease from lower stem samples that have not produced or no longer possess fungal mats. The use of this detection method in wooded areas could help to quickly identify new infection centers and lead to the rapid removal of potential spore-producing trees.

The nested PCR protocol used in this study had a higher rate of pathogen detection than the real-time PCR method. There are a variety of factors contributing to why the real-time PCR did not result in more frequent detection of $C$. fagacearum. A low starting concentration of target DNA from the drill shaving extraction could have made two consecutive rounds of PCR essential for successful amplification. Other studies using real-time PCR protocols to amplify DNA from oak sapwood drill shavings have resulted in relatively high $\mathrm{Ct}$ values and low estimated target gene region copy numbers (Lamarche et al. 2015). Kurdyla and Appel (2011) did not detect the fungus from all sapwood samples taken from symptomatic live oak trees and $\mathrm{Ct}$ values were similar to the values observed in this study.

Another explanation for the low incidence of successful amplification is the possibility of a high concentration of PCR-inhibiting compounds. Tannic acid, a polyphenolic compound found in oak bark and wood, has been shown to limit real-time PCR by inhibiting Taq polymerase and affecting the availability of template DNA (Johnson et al. 2009; Opel et al. 2010). It is possible that the second round of PCR in the nested PCR protocol created more dilute samples of tannic acid and other polyphenolic PCR inhibitors.

In this study, detection of $C$. fagacearum from sapwood drill shavings using nested and real-time PCR was compared with detection using traditional isolation methods. Although further refinements to the real-time PCR protocol may optimize results, the nested PCR protocol is ready for use in plant disease diagnostic clinics. The PCR assays tested here offer three significant improvements in detection of $C$. fagacearum. The first is an increase in detection reliability within specific sample types. The second improvement is the substantial decrease in the time it takes to detect the pathogen and, potentially, the time between diagnosis and treatment. Finally, the fungus can be detected in dead sapwood of branches and main stems within at least 1 year of branch or whole-tree wilt.

\section{Acknowledgments}

We thank D. Samac and G. Johnson for helpful comments on the manuscript; P. Castillo, A. Joy, T. Kurdyla, and M. Dornbusch for technical assistance; and arborists and city foresters for the location of sites and trees as well as assistance in sample collection. The Statistical Consulting Center at the University of Minnesota and, in particular, L. Dietz helped with the analysis of this study. This research was supported by the United States Department of Agriculture Forest Service Special Technology Development Program NA-2012-05 and the Minnesota Turf and Grounds Foundation.

\section{Literature Cited}

Agresti, A. 2002. Categorical Data Analysis. John Wiley \& Sons, Inc., Hoboken, NJ. doi: $10.1002 / 0471249688$

Appel, D. 1995. The oak wilt enigma: Perspectives from the Texas epidemic Annu. Rev. Phytopathol. 33:103-118.

Banik, M. T., Lindner, D. L., Juzwik, J., and Glaeser, J. A. 2013. Use of DNA sequencing to detect pathogenic, saprotrophic, and stain fungi in sapwood of 
declining red pine (Pinus resinosa) in the Upper Midwest. Pages 101-110 in: Proc. West. Int. For. Dis. Work Conf. Lake Tahoe, CA. J. Browning and P. Palacios, comps.

Bretz, T. W., and Morrison, D. W. 1953. Effect of time and temperature on isolation of the oak wilt fungus from infected twig samples. Plant Dis. Rep. 37:162-163.

Ginzinger, D. G. 2002. Gene amplification using real-time quantitative PCR: An emerging technology hits the mainstream. Exp. Hematol. 30:503-512.

Gould, A. B. and Lashomb, J. H. 2007. Bacterial leaf scorch (BLS) of shade trees. Online publication. Plant Health Instruct. doi:10.1094/PHI-I-2007-0403-07

Guglielmo, F., Bergemann, S. E., Gonthier, P., Nicolotti, G., and Garbelotto, M. 2007. A multiplex PCR-based method for the detection and early identification of wood rotting fungi in standing trees. J. Appl. Microbiol. 103:1490-1507.

Guglielmo, F., Gonthier, P., Garbelotto, M., and Nicolotti, G. 2010. Optimization of sampling procedures for DNA-based diagnosis of wood decay fungi in standing trees. Lett. Appl. Microbiol. 51:90-97.

Haack, R. A., and Acciavatti, R. E. 1992. Twolined Chestnut Borer. USDA Forest Service Forest Insect and Disease Leaflet 168. USDA Forest Service, North Central Forest Experiment Station, East Lansing, MI.

Jeyaprakash, A., Davison, D. A., and Schubert, T. S. 2014. Molecular detection of the laurel wilt fungus, Raffaelea lauricola. Plant Dis. 98:559-564.

Johnson, P. S., Shifley, S. R., and Rogers, R., eds. 2009. The Ecology and Silviculture of Oaks, 2nd ed. CAB International, Wallingford, Oxfordshire, UK

Juzwik, J., Appel, D. N., MacDonald, W. L., and Burks, S. 2011. Challenges and successes in managing oak wilt in the United States. Plant Dis. 95:888-900.

Kurdyla, T., and Appel, D. 2011. The detection of Ceratocystis fagacearum in Texas live oak using real-time polymerase chain reaction. (Abstr.) Phytopathology 101: S95.

Lamarche, J., Potvin, A., Pelletier, G., Stewart, D., Feau, N., Alayon, D. I. O., Dale, A. L., Coelho, A., Uzunovic, A., Bilodeau, G. J., Brière, S. C., Hamelin, R. C., and Tanguay, P. 2015. Molecular detection of 10 of the most unwanted alien forest pathogens in Canada using real-time PCR. PLoS One 10:e0134265.

Lindner, D. A., Vasaitis, R., Kubartova, A., Allmer, J., Johannesson, H., Banik, M. T., and Stenlid, J. 2011. Initial fungal colonizer affects mass log and fungal community development in Picea abies logs 6 yr after inoculation. Fungal Ecol. 4:449-460.

McCartney, H., Foster, S., Fraaije, B., and Ward, E. 2003. Molecular diagnostics for fungal plant pathogens. Pest Manage. Sci. 59:129-42.

Opel, K., Chung, D., and McCord, B. 2010. A study of PCR inhibition mechanisms using real-time PCR. J. Forensic Sci. 55:25-33.

Pokorny, J. 1999. How to collect field samples and identify the oak wilt fungus in the laboratory. NA-FR-01-99. USDA Forest Service, Northeastern Area State and Private Forestry, St. Paul, MN.

R Core Team. 2013. R: A Language and Environment for Statistical Computing. Online publication. R Foundation for Statistical Computing, Vienna. http:// www.R-project.org/

Samuelian, S. K., Greer, L. A., Savocchia, S., and Steel, C. C. 2011. Detection and monitoring of Greeneria uvicola and Colletotrichum acutatum development on grapevines by real-time PCR. Plant Dis. 95:298-303.

Schena, L., Nigro, F., Ippolito, A., and Gallitelli, D. 2004. Real-time PCR: A new technology to detect and study phytopathogenic and antagonistic fungi. Eur. J. Plant Pathol. 110:893-908.

Schoch, C. L., Seifert, K. A., Huundorf, S., Robert, V., Spouge, J. L., Levesque, C. A., and Chen, W. 2012. Nuclear ribosomal internal transcribed spacer (ITS) region as universal DNA barcode marker for fungi. Proc. Natl. Acad. Sci. USA 109:6241-6246.

Sikdar, P., Okubara, P., Mazzola, M., and Xiao, C. L. 2014. Development of PCR assays for diagnosis and detection of the pathogens Phacidiopycnis washingtonensis and Sphaeropsis pyriputrescens in apple fruit. Plant Dis. 98 241-246.

Wang, Y., Wang, Y., and Tian, C. 2013. Quantitative detection of pathogen DNA of Verticillium wilt on smoke tree Cotinus coggygria. Plant Dis. 97:1645-1651.

Wu, C. P., Chen, G. Y., Li, B., Su, H., An, Y. L., Zhen, S. Z., and Ye, J. R. 2011 Rapid and accurate detection of Ceratocystis fagacearum from stained wood and soil by nested and real-time PCR. For. Pathol. 41:15-21.

Yang, A., Juzwik, J., and Mollov, D. 2014. Use of nested PCR to detect Ceratocystis fagacearum in sapwood of diseased northern oak species. In: 2014 Am. Phytopathol. Soc. Annu. Meet., Minneapolis, MN 